\title{
Erratum to: Endocarps of menispermaceous plants in Taiwan
}

\author{
Sheng-Zehn Yang ${ }^{*}$ and Po-Hao Chen
}

\section{Erratum to: Bot Stud (2016) 57:14 \\ DOI 10.1186/s40529-016-0129-7}

In our recent article (Yang and Chen 2016), we regret that we did not acknowledge that Appendix 2 and Appendix 3 were adapted from Wefferling et al. (2013). In addition, some sentences in the Introduction and Discussion of our article were taken from Wefferling et al. (2013) to describe the menispermaceous endocarps that we studied in Taiwan. We should have ensured transparency in our article as we did not intend to attribute the prior work of Wefferling et al. to ourselves. We apologize to Wefferling et al. for the lack of appropriate attribution.

The online version of the original article can be found under doi:10.1186/s40529-016-0129-7.

\section{Publisher's Note}

Springer Nature remains neutral with regard to jurisdictional claims in published maps and institutional affiliations.

Received: 22 March 2017 Accepted: 22 March 2017

Published online: 06 April 2017

\section{References}

Wefferling KM, Hoot SB, Neves SS (2013) Phylogeny and fruit evolution in Menispermaceae. Am J Bot 100(5):883-905. doi:10.3732/ajb.1200556

Yang SZ, Chen PH (2016) Endocarps of menispermaceous plants in Taiwan. Bot Stud 57:14. doi:10.1186/s40529-016-0129-7

*Correspondence: yangsz@mail.npust.edu.tw

National Pingtung University of Science and Technology, No. 1, Shuefu

Rd., Neipu, Pingtung 912, Taiwan

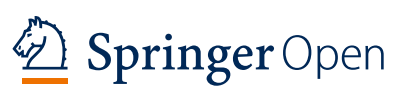

(c) The Author(s) 2017. This article is distributed under the terms of the Creative Commons Attribution 4.0 International License (http://creativecommons.org/licenses/by/4.0/), which permits unrestricted use, distribution, and reproduction in any medium, provided you give appropriate credit to the original author(s) and the source, provide a link to the Creative Commons license, and indicate if changes were made. 